\title{
Montelukast: The New Therapeutic Option for the Treatment of Epilepsy
}

This article was published in the following Dove Press journal:

Journal of Experimental Pharmacology

\section{Bekalu Amare Tesfaye (DD Haftom Gebregergs Hailu (D) Kaleab Alemayehu Zewdie (ID) Muluken Altaye Ayza (D) Derbew Fikadu Berhe (D)}

Department of Pharmacology and Toxicology, School of Pharmacy, Mekelle University, Mekelle, Ethiopia
Correspondence: Haftom Gebregergs Hailu

Tel +25 I 912085606

Fax +25I3444I668I

Email haftomphar@gmail.com
Abstract: Currently, there is no definitive cure for epilepsy. The available medications relieve symptoms and reduce seizure attacks. The major challenge with the available antiepileptic medication is safety and affordability. The repurposing of montelukast for epilepsy can be an alternative medication with a better safety profile. Montelukast is a leukotriene receptor antagonist that binds to the cysteinyl leukotrienes (CysLT) receptors used in the treatment of bronchial asthma and seasonal allergies. Emerging evidence suggests that montelukast's anti-inflammatory effect can help to maintain BBB integrity. The drug has also neuroprotective and anti-oxidative activities to reduce seizure incidence and epilepsy. The present review summarizes the neuropharmacological actions of montelukast in epilepsy with an emphasis on the recent findings associated with Cys $L T$ and cell-specific effects.

Keywords: repurposing, seizure, inflammation, cysteinyl leukotriene receptors

\section{Introduction}

Epilepsy is one of the most common chronic brain diseases and it affects over 70 million people worldwide. ${ }^{1}$ Epilepsy is life-altering, in part, because it is unpredictable, and as such it curtails daily activities like driving, attending school, and working. ${ }^{2}$ Available anti-epilepsy treatment options include medications, keto diets, vagal nerve stimulation, and surgery. ${ }^{3}$ However, the currently available antiepileptic medications do not bring a definitive cure. ${ }^{4}$ More than one-third of the epileptic patients who take the currently available drugs do not get the required benefit. These drugs also have serious side effects. ${ }^{5}$ Particularly, pregnant women, children, the elderly, and patients with chronic comorbidities such as chronic kidney or liver disease are at higher risk of toxicity from those drugs. ${ }^{6,7}$ Developing a new anti-epileptic medication could be expensive and time consuming. Repurposing available medications could reduce the cost and time required for the discovery of new anti-epileptic drug.

Montelukast is a cysteine leukotriene receptors (CysLTR) antagonist which is currently being used for the treatment of bronchial asthma and seasonal allergies. ${ }^{8,9}$ In recent years, montelukast has been reported to have beneficial pharmacological effects in the nervous, ${ }^{10}$ cardiovascular, ${ }^{8}$ and cerebrovascular systems. ${ }^{11}$ Epidemiologic studies have shown that montelukast reduces the incidence and severity of seizures. ${ }^{12,13}$ These results indicate that montelukast could be developed into a disease-modifying drug for epilepsy. This review summarizes the current findings on the role of montelukast to control seizures. 


\section{Epilepsy Pathophysiology and Cysteine Leukotrienes}

Leukotrienes (LTs) are one of the major constituents of biologically active eicosanoids. ${ }^{14}$ LTs are secreted during inflammation by mast cells, eosinophil, and leukocytes. ${ }^{15}$ They possess a wide range of biological activities including leukocyte chemotaxis, vascular leakage, endothelial cell migration, smooth muscle cells and astrocyte proliferation. $^{15}$

In the human body, LTs are derived de novo from arachidonic acid (AA). ${ }^{16} \mathrm{AA}$ is released from membrane phospholipids through the action of phospholipase A2. ${ }^{17}$
The biosynthesis of LTs from AA is dependent on the action of the enzyme 5-lipoxygenase and its activating protein, 5-lipoxygenase activating protein (FLAP). ${ }^{8}$ There are five types of LTs: leukotriene A4 (LTA4), leukotriene B4 (LTB4), leukotriene C4 (LTC4), leukotriene D4 (LTD4), and leukotriene E4 (LTE4). ${ }^{16}$ LTA4 and LTB4 are non-cysteinyl leukotrienes as they lack the cysteine moiety ${ }^{18}$ which is present in the Cys-LTs (LTC4, LTD4, and LTE4) $)^{15}$ (Figure 1).

Cysteinyl leukotrienes exhibit several biological activities in nanomolar concentrations through at least two specific G-protein coupled receptor subtypes named

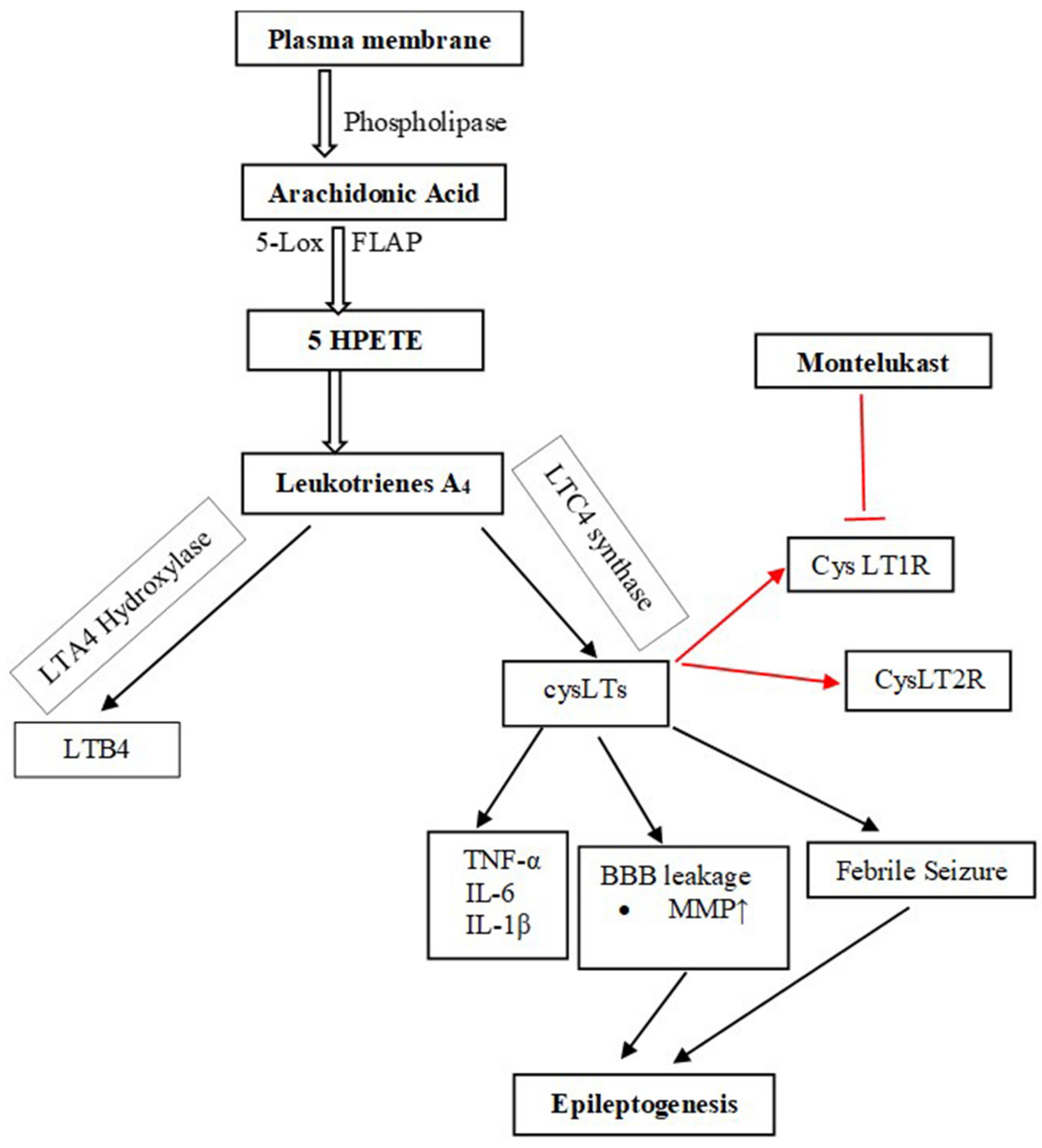

Figure I Biosynthesis pathway of the Cys-LT and their receptors. Biosynthesis of CysLTs starts with the release of arachidonic acid from plasma membrane by the action of phospholipase. Arachidonic acid is metabolized to leukotriene $A_{4}$ that in turn is metabolized to both non-cysteine leukotriene, LTB4, and cysteine leukotrienes. The CysLTs act on the receptors, CysLTIR and CysLT2R. Montelukast competitively block the effects of CysLTs on these receptors. The red color of the arrows show the site where montelukast acts.

Abbreviations: 5-Lox, 5-lipoxygenase; FLAP, 5-lipoxygenase activating protein; 5HPETE, 5-hydroperoxyeicosatetraenoic acid; LTB4, leukotriene B4; CysLTs, cysteinyl leukotrienes; CysLTIRs, cysteinyl leukotrienes I receptor; CysLT2Rs, cysteinyl leukotrienes I receptor; TNF- $\alpha$, tumour necrosis factor alpha; IL-6, interleukin-6; IL-I $\beta$, interleukin I beta; MMP, matrix metallopeptidases. 
CysLTR-1 and CysLTR-2 which show 38\% homolog. ${ }^{19}$ Different studies have demonstrated that binding of LTD4 to the CysLT1 receptor leads to G-protein activation and the release of secondary intracellular messengers including diacylglycerol, inositol phosphates, and $\mathrm{Ca} 2 \mathrm{p}$. This is followed by the activation of protein kinase $\mathrm{C}$ and accompanied by the mobilization of $\mathrm{Ca} 2 \mathrm{p}$ derived from both intracellular and extracellular stores. ${ }^{20,21}$ Furthermore, CysLT1 receptor activation by LTD4 has been reported to be associated with a transduction system based on the activation of phosphoinositide-3-kinase, extracellular-receptor kinase, mitogen-activated protein kinase, nuclear factor-kB (NF-kB), tumor necrosis factor, and matrix metalloproteinases- 9 pathway. $^{22}$

Cys-LTs also induce the release of Matrix metallopeptidases (MMPs), including MMP-2 and MMP-9, inflammatory cytokines such as interleukins (ILs), NF-kB, and tumor necrosis factor- $\alpha$ (TNF- $\alpha$ ) from macrophages through the cys-LT1 receptor. $^{23,24}$ The release of these inflammatory mediators was highly associated with Amyloid beta1-42 (Ab1-42) induced cytotoxicity. ${ }^{10}$

LTs and 5-lipoxygenase metabolite overexpression cause severe tissue damage. Relative to airway inflammation, many mediators, such as orupeptides and substance $\mathrm{P}$, play a role in many of these interactions with LTs. ${ }^{25}$ During inflammatory activation, LTs are synthesized and become functional. CysLTs induce smooth muscle contraction, vascular leakage, ${ }^{26}$ eosinophil recruitment, mucus production and chemotaxis. LTB4 induces leukocyte chemoattraction, particularly of granulocytes and $\mathrm{T}$ cells, rapid invasion and recruitment of these cells to the plasma membrane of endothelial cells and production of reactive oxygen species. ${ }^{18}$ CysLTs bind to their two receptors, CysLT1R and CysLT2R. These receptors are therapeutic targets for drug development to cure asthma and other immune diseases. ${ }^{27}$ CysLT1 receptors also mediate astrocyte proliferation, which is the basis of post-ischaemic astrocytosis and glial scar formation. ${ }^{28}$ CysLT1 receptor antagonists can inhibit ischaemia-like injury-induced astrocytosis, thereby inhibiting glial scar formation. ${ }^{29}$

The role of inflammation in central nervous system disease pathogenesis has already been widely investigated, and elevated serum inflammatory mediators have been found in many neurological disorders. ${ }^{30}$ Experimental and clinical studies have shown that seizures induce brain inflammation and recurrent seizures perpetuate chronic inflammation. ${ }^{31}$ In a healthy brain, the expression of the CysLTRs is weak, but it was reported to increase during several pathological conditions. ${ }^{19}$ Earlier studies have associated CysLTs and their receptors with several neurodegenerative disorders like, multiple sclerosis, parkinson's disease, Huntington's disease, epilepsy, traumatic brain injury $^{32,33}$ and alzheimer's disease. ${ }^{18}$

Emerging evidence indicates that inflammatory mediators including LTD4 play a relevant role in the pathophysiology of epilepsy. ${ }^{19}$ However, only a few studies have investigated the role of LOX-derived arachidonic acid metabolites in epilepsy. Leukotriene levels were found to increase in a time-dependent manner in the brain during kainate-induced seizures in rats. Besides, LTD4 Intracerebroventricular (ICV) injection facilitated pentylenetetrazol (PTZ) induced seizures and increased Blood Brain Barrier (BBB) permeability in mice. ${ }^{34}$ This effect could be relevant since magnetic resonance imaging studies in patients with post-traumatic epilepsy demonstrated that the site of increased BBB permeability colocalized with the presumed epileptic focus and animal studies found a positive correlation between the extent of BBB opening and the number of seizures. ${ }^{35}$

Chemically induced seizures in rodents are associated with an early upregulation of hippocampal 5-lipoxygenase enzyme and resultant accumulation of leukotrienes. ${ }^{21}$ Spontaneously epileptic gerbils have demonstrated higher levels of cysteinyl-leukotriene formation in their brain tissue than their normal counterparts. ${ }^{36}$ Leukotrienes level increased in the brain during kainate-induced seizures. $^{34}$

In addition, kainic acid-induced seizures are associated with increased brain levels of leukotrienes and PGF2a in the cortex, hippocampus, and hypothalamus of rats. ${ }^{37}$ The effects of pharmacological treatment, kindling, and challenge with PTZ on CysLT1 and CysLT2 receptor immunoreactivity in the cerebral cortex of mice were examined. It was found that epilepsy is associated with increased levels of inflammatory mediators in the brain, including leukotrienes, which are produced by neurons, glia, and endothelial cells in the BBB. ${ }^{12}$ Neutrophils that have breached the BBB can lead to the immediate synthesis of CysLTs. $^{38}$ Farias et al demonstrated that cysLTs significantly increase after fluid percussioninduced brain injury, being detected as early as $10 \mathrm{~min}$ after injury and continuing to rise over an hour. ${ }^{39}$ A pharmacological data provided by Lenz et al also indicated that CysLT1R antagonism maintains BBB integrity. ${ }^{34}$ In accordance, Palmer et al demonstrated that LTD4 increases the firing rate of Purkinje cells in vivo, 
suggesting an excitatory role for this lipid mediator. ${ }^{40}$ Glutamate released during seizures acts on capillary NMDA receptors to cause blood-brain barrier disruption through cPLA2, COX-2 and 5-LOX leading to increased MMP expression, degradation of Tight Junction Proteins (TJs) and increased barrier leakage which increases the likelihood of further seizures. ${ }^{41,42}$

Pharmacological modulation of 5-lipooxygenase, an enzyme required for the biosynthesis of leukotrienes, has been shown to potentiate the protective effect of a COX-2 inhibitor on kainic acid induced seizures in rodents. ${ }^{21}$ Inhibition of LOX using dual inhibitors of LOX/COX pathway like phenidone and BW755C has led to decreased production of CysLTs and attenuated seizure activity, respectively. ${ }^{43}$ Similarly, zileuton, a LOX inhibitor, was shown to decrease spike-wave discharges in pilocarpineinduced epileptic rats, strongly suggesting that leukotrienes play a role in epilepsy. ${ }^{19}$ Montelukast, a CysLT1 receptor inverse agonist and 1,2,3,4-tetrahydroisoquinoline, regarded as a LTD4 synthetic pathway inhibitor, dose-dependently suppress the development of kindled seizures, as well as pilocarpine-induced spontaneous recurrent seizures. ${ }^{21}$ Interestingly, it has been shown that while LTD4 facilitates, montelukast, pranlukast and Bay-u9773 (a dual CysLT1/CysLT2 antagonist) decrease PTZ-induced seizures and BBB permeability disruption. Pranlukast, zafirlukast and montelukast are cysLT-1 antagonists that are available in the market. ${ }^{44}$

\section{Repurposing of Montelukast as an Antiepileptic Drug}

Montelukast, 1-((1(R)-(3-(2-(7-chloro-2-quinolinyl)-(E)ethenyl)phenyl)-3-[(2-(1-hydroxy-1-methylethyl)phenyl) propyl)thiol]-methyl)] cyclopropane acetate, is a selective CysLT1 receptor antagonist ${ }^{45}$ possessing antiinflammatory effects and has been widely used for the treatment of inflammatory diseases such as asthma and allergic rhinitis. ${ }^{46}$ Montelukast was approved for use in the United States in 1998 and is widely used with more than 20 million prescriptions being filled yearly. ${ }^{47}$ Montelukast is the most prescribed CysLT1 receptor antagonist in Europe and the USA. ${ }^{48}$

Montelukast showed a neuroprotective effect through antioxidant, anti-inflammatory, and antiapoptotic mechanisms. $^{49}$ It is reported to have a neuroprotective activity in several neuronal disorders such as alzheimer's disease, cerebral ischemia, multiple sclerosis and seizures. ${ }^{13,50}$ Other studies also displayed that it possesses a wide spectrum of anti-inflammatory properties in several chronic diseases. ${ }^{8}$ The evidences of the antiepileptic activities of montelukast from animal studies are summarized below (Table 1).

Montelukast protected hippocampal tissue by reducing oxidative stress, inflammatory and apoptotic markers. ${ }^{11}$ Furthermore, it reduced glutamate and lactate dehydrogenase activity as well as infarct size elevated by ischemia/ reperfusion. ${ }^{49}$ Montelukast markedly reduced ox-LDLinduced adhesion of monocytes to endothelial cells. ${ }^{8}$ An in vitro study has recently shown that montelukast suppressed phagocytosis induced by rotenone and decreased the subsequent proinflammatory cytokine release. ${ }^{36}$

Montelukast Suppresses inflammatory mediators induced by TNF-a. ${ }^{23}$ It induces M2 macrophages ${ }^{51}$ polarization which is important in the removal of cellular debris, embryonic development, and tissue repair. ${ }^{52}$ It also suppresses the activity of MMP-2 and MMP-9. ${ }^{53}$ Montelukast, MK571, and zafirlukast (inverse agonists of CysLT1R) increased cell surface receptor expression in COS-7 cells while LTD4 (a CysLT1 receptor agonist) did the opposite. ${ }^{12}$ Several forms of brain injuries trigger leukotriene production, including ischemia, trauma, stroke, and seizures, which are associated with increased BBB permeability. ${ }^{54}$ Epilepsy-related $\mathrm{BBB}$ disruption is mediated by Cys-LT and modulation of Cys-LT by montelukast suppresses the development and frequency of seizures in vivo. ${ }^{34}$ Montelukast and LTD4, respectively, reduced and increased the $\mathrm{BBB}$ disruption induced by PTZ. ${ }^{12}$ Montelukast prevented PTZ-induced BBB disruption by inhibiting paracellular diffusion and leukocyte infiltration and slowing the onset of PTZ-induced seizures. ${ }^{34}$ Obermeier et al's finding indicated that the maintenance of BBB integrity may underlie the currently reported anticonvulsant effect of CysLT1R antagonists. ${ }^{55}$ Intracerebroventricular injection of montelukast prevented seizures and maintained the BBB integrity at the same range of doses and increased latency to seizures correlated with low BBB permeability scores. ${ }^{34}$

Moreover, the ICV injection of LTD4 facilitates the convulsant effect of PTZ and reverts the anticonvulsant action of montelukast which constitutes converging pharmacological evidence for the involvement of CysLT receptors in seizures. ${ }^{12,19}$ The two other CysLT receptor antagonists (pranlukast and Bay-u9973) also decreased PTZ-induced seizures which indicated that CysLT receptors' role in seizures. ${ }^{45,56}$ Montelukast suppressed the 
Table I Preclinical Studies Done on the Antiepileptic Effect of Montelukast

\begin{tabular}{|c|c|c|c|c|}
\hline Experimental Approaches & Study Subjects & Interventions & Major Outcome(s) & References \\
\hline PTZ-induced seizures & $\begin{array}{l}\text { Male Swiss mice } \\
\text { weighed between } \\
25-28 \mathrm{~g} \text { and aged } \\
42 \text { days }\end{array}$ & $\begin{array}{l}\text { Three groups of PTZ kindled } \\
\text { mice: phenobarbital treated } \\
\text { group, montelukast treated group, } \\
\text { and normal saline treated group }\end{array}$ & $\begin{array}{l}\text { Both montelukast and } \\
\text { phenobarbital improved the } \\
\text { latency period to generalized } \\
\text { seizures. }\end{array}$ & {$[12]$} \\
\hline $\begin{array}{l}\text { Montelukast against PTZ induced } \\
\text { acute seizure }\end{array}$ & $\begin{array}{l}\text { II } 2 \text { adult Swiss } \\
\text { albino male mice } \\
\text { weighing } 15-35 g \\
\text { and aged } 8 \text { weeks } \\
\text { were used }\end{array}$ & $\begin{array}{l}\text { Two animal study models were } \\
\text { used. The first was an acute PTZ } \\
\text { model where mice were divided } \\
\text { into five groups and treated with } \\
\text { single IP dose; saline, PTZ, } \\
\text { valproate, montelukast, and both } \\
\text { montelukast and valproate. } \\
\text { The second was a kindling model } \\
\text { where mice were divided into five } \\
\text { groups and treated daily for I7 } \\
\text { days IP with; saline, PTZ, } \\
\text { valproate, montelukast, both } \\
\text { montelukast, and valproate. }\end{array}$ & $\begin{array}{l}\text { Montelukast, alone or in } \\
\text { combination with valproate } \\
\text { blocked CysLTRs and protected } \\
\text { the mice's brain against PTZ } \\
\text { induced seizures. Montelukast, } \\
\text { alone or in combination with } \\
\text { valproate also reduced oxidative } \\
\text { stress and inflammatory cascades. } \\
\text { The authors reported } \\
\text { a significantly increased level of } \\
\text { GSH and significantly reduced } \\
\text { levels of MDA, ILI } \beta \text {, TNF } \alpha \text {, and } \\
\text { LTD4 as compared to PTZ } \\
\text { treated control groups. }\end{array}$ & [69] \\
\hline $\begin{array}{l}\text { PTZ-induced seizure: } \\
\text { electroencephalography (EEG), } \\
\text { Racine's Convulsion Scale (RCS), } \\
\text { onset times of first myoclonic jerk } \\
\text { (FMJ), Malondialdehyde (MDA) and } \\
\text { superoxide dismutase (SOD) levels } \\
\text { were determined }\end{array}$ & $\begin{array}{l}48 \text { male Sprague- } \\
\text { Dawley rats were } \\
\text { used (weighed } \\
\text { between } \\
200-250 \mathrm{~g} \text { ) }\end{array}$ & $\begin{array}{l}\text { Rats were grouped into two as } \\
\text { group "A" to study EEG and "B" } \\
\text { for behavioral studies. Group "A" } \\
\text { were further divided into AI, A2, } \\
\mathrm{A} 3 \text {, and A4 and treated with IP; } \\
\text { normal saline and } 25,50 \text {, and } \\
100 \mathrm{mg} / \mathrm{kg} \text { of montelukast. } \\
\text { Animals in Group "B" were } \\
\text { similarly divided as } \mathrm{B}_{1} \mathrm{~B}_{2}, \mathrm{~B}_{3} \text {, and } \\
\mathrm{B}_{4} \text { and treated with IP normal } \\
\text { saline and } 25,50 \text {, and } 100 \mathrm{mg} / \mathrm{kg} \\
\text { of montelukast. }\end{array}$ & $\begin{array}{l}\text { Montelukast showed significant } \\
\text { anticonvulsant and anti-oxidant } \\
\text { action. Rats administered with } 50 \\
\text { or } 100 \mathrm{mg} / \mathrm{kg} \text { of montelukast } \\
\text { significantly lowered RCS and } \\
\text { significantly elevated FMJ onset } \\
\text { time compared to the controls. } \\
\text { A significantly lower MDA and } \\
\text { higher SOD levels were also } \\
\text { found in the animals treated with } \\
25,50 \text {, or I00 mg/kg ( } \mathrm{p}<0.00 \mathrm{I} \text { ) of } \\
\text { montelukast as compared to the } \\
\text { saline treated group. }\end{array}$ & [13] \\
\hline $\begin{array}{l}\text { Isobolographic analysis of the } \\
\text { synergistic activity of montelukast } \\
\text { and phenobarbital on PTZ induced } \\
\text { seizures }\end{array}$ & $\begin{array}{l}\text { A total of } 134 \\
\text { adult female } \\
\text { Swiss mice ( } 25 \pm \\
3 \text { g) were used: }\end{array}$ & $\begin{array}{l}\text { Five different groups of animals } \\
\text { were treated with montelukast, } \\
\text { phenobarbital, montelukast plus } \\
\text { phenobarbital, montelukast plus } \\
\text { LTD4, and vehicle respectively. }\end{array}$ & $\begin{array}{l}\text { The combination of montelukast } \\
\text { and phenobarbital was found to } \\
\text { have a synergistic effect. The } \\
\text { group of animals treated with the } \\
\text { combination showed an increased } \\
\text { latency period to PTZ-induced } \\
\text { tonic-colonic seizures. The ED50 } \\
\text { of phenobarbital for anti-seizure } \\
\text { activity was also significantly } \\
\text { lowered by montelukast. }\end{array}$ & [70] \\
\hline $\begin{array}{l}\text { Effect of CYSLT receptor } \\
\text { antagonists on PTZ induced } \\
\text { seizure and BBB integrity }\end{array}$ & $\begin{array}{l}\text { Male albino Swiss } \\
\text { mice weighing } 25 \\
\pm 3.5 \mathrm{gm} \text { were } \\
\text { used }\end{array}$ & $\begin{array}{l}\text { Mice were divided into five groups } \\
\text { and treated with the antagonists } \\
\text { (montelukast, pranlukast, Bay } \\
\mathrm{u}-9773 \text { ), agonist }\left(\mathrm{LTD}_{4} \text { ), and }\right. \\
\text { a solvent respectively. This was } \\
\text { followed by an injection with PTZ } \\
\text { after } 30 \text { minutes. }\end{array}$ & $\begin{array}{l}\text { All three antagonists prolonged } \\
\text { the latency period to generalized } \\
\text { seizures. They also decreased } \\
\text { mean EEG amplitudes during } \\
\text { seizure episodes. Montelukast } \\
\text { also stopped PTZ induced BBB } \\
\text { leakages. }\end{array}$ & [34] \\
\hline
\end{tabular}

(Continued) 
Table I (Continued).

\begin{tabular}{|c|c|c|c|c|}
\hline Experimental Approaches & Study Subjects & Interventions & Major Outcome(s) & References \\
\hline $\begin{array}{l}\text { Effect of montelukast and I,2,3,4, } \\
\text { tetrahydroisoquinoline on PTZ } \\
\text { induced seizures and pilocarpine } \\
\text { induced status epilepticus }\end{array}$ & $\begin{array}{l}\text { Male albino mice } \\
\text { weighed } 25 \pm 2 g \\
\text { were used }\end{array}$ & $\begin{array}{l}\text { Animals categorized into } 8 \text { groups } \\
\text { as Group I - Group VIII were } \\
\text { treated with vehicle only, PTZ } \\
\text { only, low dose montelukast plus } \\
\text { PTZ, medium dose montelukast } \\
\text { plus PTZ, high dose montelukast } \\
\text { plus PTZ, low dose I,2,3,4 } \\
\text { tetrahydroisoquinoline plus PTZ, } \\
\text { medium dose I,2,3,4 } \\
\text { tetrahydroisoquinoline plus PTZ, } \\
\text { and high dose I,2,3,4 } \\
\text { tetrahydroisoquinoline plus PTZ } \\
\text { respectively. }\end{array}$ & $\begin{array}{l}\text { Both montelukast and } 1,2,3,4 \text {, } \\
\text { tetrahydroisoquinoline halted the } \\
\text { development of PTZ kindled } \\
\text { seizure and pilocarpine-induced } \\
\text { status epilepticus significantly and } \\
\text { in a dose-dependent manner. }\end{array}$ & {$[21]$} \\
\hline
\end{tabular}

development of kindled seizures, as well as pilocarpineinduced spontaneous recurrent seizures in mice. Clinical evidence highlights the efficacy of cysLT receptor antagonists such as pranlukast in patients with intractable partial epilepsy. ${ }^{57}$ Pranlukast reduced seizure frequencies probably normalizing MMP-9 in serum, reducing leakage of proinflammatory cytokines into CNS, and inhibiting extravasation of leucocytes from brain capillaries. ${ }^{19,57}$ Inflammatory cytokines and matrix metalloproteinases that cause degradation of the extracellular matrix IL-1 and TNF- $\alpha$ receptors are rapidly upregulated in neurons during seizures, suggesting that they mediate the effects of cytokines on neuronal excitability. ${ }^{58}$ Cytokine receptors in the CNS are expressed by neurons, microglia, ${ }^{59}$ and astrocytes. ${ }^{60}$ Evidence exists for cell type-specific IL-1 $\beta$ signaling in the CNS through the IL-1 type 1 receptor: IL$1 \beta$ activates the $\mathrm{p} 38$ mitogen-activated protein kinase pathway in neurons, leading to induction of cyclic adenosine monophosphate response element-binding protein, whereas NF- $\mathrm{KB}$ is activated predominantly in astrocytes, suggesting that this cytokine may have distinct functional effects on neurons and glia. ${ }^{61}$

Ab1-42-induced CysLT1R expression results in neurotoxicity, inflammatory and apoptotic responses in cultured primary neurons. ${ }^{62,63} \mathrm{Ab1-42}$ is involved in the pathologic mechanisms of axon damage, axon growth, and network reorganization observed in refractory epilepsy ${ }^{64}$ and late onset epilepsy of unknown origin mediated by D1 receptor. ${ }^{65}$ This is because of Ab1-42 activated nuclear factor kappa-light-chain-enhancer of activated B cells (NF-kB) signaling by selectively inducing the nuclear translocation of p65 and p50 subunits, and promoting expression of genes such as proinflammatory or apoptotic profile. ${ }^{66}$ Treatment with montelukast was able to decrease this increment of nuclear p65 subunit which indicates that montelukast may block Ab1-42-activated NF- $\kappa \mathrm{B}$ signaling in primary neurons. ${ }^{10,67}$ Moreover, blockade of CysLT1R with montelukast reversed Ab1-42-mediated increase of CysLT1R expression, and concomitant changes of the pro-inflammatory factors and the apoptosis-related proteins which result in Ab1-42-associated late onset of epilepsy. ${ }^{68}$

\section{Conclusion}

Overexpression of cysLT in the brain causes the tissue damage, which is responsible for the pathogenesis of many neurological disorders including epilepsy. Various experimental studies indicated that montelukast which is a potent cys $L T$ receptor antagonist blocked CNS inflammation resulting in neuro-protection, treating febrile seizures, potentiate the action of the old antiepileptic drugs, and maintained BBB integrity from dysfunction. It is also relatively safe drug as it has been used for the treatment of asthma for more than two decades. Therefore, montelukast has the potential to be an alternative treatment for epilepsy. However, further studies of both preclinical and clinical studies are required before considering montelukast for a prescription to treat epilepsy.

\section{Author Contributions}

All authors made a significant contribution to the work reported, whether that is in the conception, study design, execution, acquisition of data, analysis and interpretation, 
or in all these areas; took part in drafting, revising or critically reviewing the article; gave final approval of the version to be published; have agreed on the journal to which the article has been submitted; and agree to be accountable for all aspects of the work.

\section{Disclosure}

The authors declare no conflicts of interest in this work.

\section{References}

1. Thijs RD, Surges R, O'Brien TJ, Sander JW. Epilepsy in adults. Lancet. 2019;393(10172):689-701. doi:10.1016/S0140-6736(18) 32596-0

2. Brueggeman L, Sturgeon ML, Martin RM, et al. Drug repositioning in epilepsy reveals novel antiseizure candidates. Ann Clin Transl Neurol. 2019;6(2):295-309. doi:10.1002/acn3.703

3. Guberman A. Vagus nerve stimulation in the treatment of epilepsy. Cmaj. 2004;171(10):1165-1166. doi:10.1503/cmaj.1041039

4. D'Ambrosio R, Eastman CL, Fattore C, Perucca E. Novel frontiers in epilepsy treatments: preventing epileptogenesis by targeting inflammation. Expert Rev Neurother. 2013;13(6):615-625. doi:10.1586/ern.13.54

5. Ventola CL. Epilepsy management: newer agents, unmet needs, and future treatment strategies. Pharm Ther. 2014;39(11):776.

6. Asconapé JJ. Use of antiepileptic drugs in hepatic and renal disease. In: Handbook of Clinical Neurology. Vol. 119. Elsevier; 2014:417-432.

7. Wahab A. Difficulties in treatment and management of epilepsy and challenges in new drug development. Pharmaceuticals. 2010;3 (7):2090-2110. doi:10.3390/ph3072090

8. Zhou L, Sun X, Shi Y, Liu J, Luan G, Yang Y. Cysteinyl leukotriene receptor type 1 antagonist montelukast protects against injury of blood-brain barrier. Inflammopharmacology. 2019;27(5):933-940. doi:10.1007/s10787-019-00611-7

9. Scholz BH. Neuropsychiatric disorder and montelukast: a case report and vigibase ${ }^{\circledR}$ analysis. Arch Dis Child. 2019;104(1):54-55.

10. Lai J, Mei ZL, Wang H, et al. Montelukast rescues primary neurons against $A \beta 1-42$-induced toxicity through inhibiting CysLT1R-

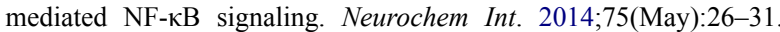
doi:10.1016/j.neuint.2014.05.006

11. Hoxha M, Lewis-Mikhael A-M, Bueno-Cavanillas A. Potential role of leukotriene receptor antagonists in reducing cardiovascular and cerbrovascular risk: a systematic review of human clinical trials and in vivo animal studies. Biomed Pharmacother. 2018;106:956-965. doi:10.1016/j.biopha.2018.07.033

12. Fleck J, Temp FR, Marafiga JR, et al. Montelukast reduces seizures in pentylenetetrazol-kindled mice. Brazilian J Med Biol Res. 2016;49 (4):1-7. doi:10.1590/1414-431X20155031

13. Cevik B, Solmaz V, Aksoy D, Erbas O. Montelukast inhibits pentylenetetrazol-induced seizures in rats. Med Sci Monit. 2015;21:869-874. doi:10.12659/MSM.892932

14. Wang D, DuBois RN. Eicosanoids and cancer. Nat Rev Cancer. 2010;10(3):181. doi:10.1038/nrc2809

15. Ghosh A, Chen F, Thakur A, Hong H. Cysteinyl leukotrienes and their receptors: emerging therapeutic targets in central nervous system disorders. CNS Neurosci Ther. 2016;22(12):943-951. doi:10.1111/cns.12596

16. Izumi $T$, Yokomizo $T$, Obinata $H$, Ogasawara $H$, Shimizu $T$. Leukotriene receptors: classification, gene expression, and signal transduction. $J$ Biochem. 2002;132(1):1-6. doi:10.1093/oxfordjournals.jbchem.a003185
17. Sun GY, Shelat PB, Jensen MB, He Y, Sun AY, Simonyi A. Phospholipases A2 and inflammatory responses in the central nervous system. Neuromolecular Med. 2010;12(2):133-148. doi:10.1007/ s12017-009-8092-z

18. Rahman SO, Singh RK, Hussain S, Akhtar M, Najmi AK. A novel therapeutic potential of cysteinyl leukotrienes and their receptors modulation in the neurological complications associated with Alzheimer's disease. Eur $J$ Pharmacol. 2019;842:208-220. doi:10.1016/j.ejphar.2018.10.040

19. Gelosa P, Colazzo F, Tremoli E, Sironi L, Castiglioni L. Cysteinyl leukotrienes as potential pharmacological targets for cerebral diseases. Mediators Inflamm. 2017;2017:1-15. doi:10.1155/2017/ 3454212

20. Williamson JR, Cooper RH, Joseph SK, Thomas AP. Inositol trisphosphate and diacylglycerol as intracellular second messengers in liver. Am J Physiol Physiol. 1985;248(3):C203-C216. doi:10.1152/ajpcell.1985.248.3.C203

21. Rehni AK, Singh TG. Modulation of leukotriene D4 attenuates the development of seizures in mice. Prostaglandins Leukot Essent Fat Acids. 2011;85(2):97-106. doi:10.1016/j.plefa.2011.04.003

22. Savari S, Vinnakota K, Zhang Y, Sjölander A. Cysteinyl leukotrienes and their receptors: bridging inflammation and colorectal cancer. World J Gastroenterol. 2014;20(4):968. doi:10.3748/wjg.v20.i4.968

23. Kawai Y, Narita Y, Yamawaki-Ogata A, Usui A, Komori K. Montelukast, a cysteinyl leukotriene receptor 1 antagonist, induces $\mathrm{m} 2$ macrophage polarization and inhibits murine aortic aneurysm formation. Biomed Res Int. 2019;2019:1-11. doi:10.1155/2019/ 9104680

24. Yokomizo T, Nakamura M, Shimizu T. Leukotriene receptors as potential therapeutic targets. J Clin Invest. 2018;128(7):2691-2701. doi:10.1172/JCI97946

25. Kaya Z, Yayla M, Cinar I, et al. Effect of montelukast, a cysteinyl leukotriene receptor-1 antagonist, on a rat model of acute bacterial sinonasal inflammation. Am J Rhinol Allergy. 2019;33(5):559-566. doi: $10.1177 / 1945892419852576$

26. Dupré DJ, Le Gouill C, Gingras D, Rola-Pleszczynski M, Staňková J. Inverse agonist activity of selected ligands of the cysteinyl-leukotriene receptor 1. J Pharmacol Exp Ther. 2004;309 (1):102-108. doi:10.1124/jpet.103.059824

27. Laidlaw TM, Boyce JA. Cysteinyl leukotriene receptors, old and new; implications for asthma. Clin Exp Allergy. 2012;42 (9):1313-1320. doi:10.1111/j.1365-2222.2012.03982.x

28. Ciccarelli R, D’Alimonte I, Santavenere C, et al. Cysteinyl-leukotrienes are released from astrocytes and increase astrocyte proliferation and glial fibrillary acidic protein via cys-LT1 receptors and mitogen-activated protein kinase pathway. Eur J Neurosci. 2004;20 (6):1514-1524. doi:10.1111/j.1460-9568.2004.03613.x

29. Robel S. Astroglial scarring and seizures: a cell biological perspective on epilepsy. Neurosci. 2017;23(2):152-168.

30. Skaper SD, Facci L, Zusso M, Giusti P. An inflammation-centric view of neurological disease: beyond the neuron. Front Cell Neurosci. 2018;12:72.

31. Vezzani A, French J, Bartfai T, Baram TZ. The role of inflammation in epilepsy. Nat Rev Neurol. 2011;7(1):31. doi:10.1038/ nrneurol.2010.178

32. Sharma R, Leung WL, Zamani A, O'brien TJ, Espinosa PMC, Semple BD. Neuroinflammation in post-traumatic epilepsy: pathophysiology and tractable therapeutic targets. Brain Sci. 2019;9 (11):318. doi:10.3390/brainsci9110318

33. Lucas S, Rothwell NJ, Gibson RM. The role of inflammation in CNS injury and disease. Br J Pharmacol. 2006;147(S1):S232-S240. doi:10.1038/sj.bjp.0706400

34. Lenz QF, Arroyo DS, Temp FR, et al. Cysteinyl leukotriene receptor (CysLT) antagonists decrease pentylenetetrazol-induced seizures and blood-brain barrier dysfunction. Neuroscience. 2014;277:859-871. doi:10.1016/j.neuroscience.2014.07.058 
35. Vezzani A, Friedman A, Dingledine RJ. The role of inflammation in epileptogenesis. Neuropharmacology. 2013;69:16-24. doi:10.1016/j. neuropharm.2012.04.004

36. Mansour RM, Ahmed MAE, El-Sahar AE, El Sayed NS. Montelukast attenuates rotenone-induced microglial activation/p38 MAPK expression in rats: possible role of its antioxidant, anti-inflammatory and antiapoptotic effects. Toxicol Appl Pharmacol. 2018;358 (September):76-85. doi:10.1016/j.taap.2018.09.012

37. Sperk G, Lassmann H, Baran H, Kish SJ, Seitelberger F, Hornykiewicz O. Kainic acid induced seizures: neurochemical and histopathological changes. Neuroscience. 1983;10(4):1301-1315. doi:10.1016/0306-4522(83)90113-6

38. Michael J, Marschallinger J, Aigner L. The leukotriene signaling pathway: a druggable target in Alzheimer's disease. Drug Discov Today. 2019;24(2):505-516. doi:10.1016/j.drudis.2018.09.008

39. Farias S, Frey LC, Murphy RC, Heidenreich KA. Injury-related production of cysteinyl leukotrienes contributes to brain damage following experimental traumatic brain injury. $J$ Neurotrauma. 2009;26(11):1977-1986. doi:10.1089/neu.2009.0877

40. Palmer MR, Mathews WR, Hoffer BJ, Murphy RC. Electrophysiological response of cerebellar Purkinje neurons to leukotriene D4 and B4. J Pharmacol Exp Ther. 1981;219(1):91-96.

41. Van Vliet EA, Otte WM, Wadman WJ, et al. Blood-brain barrier leakage after status epilepticus in rapamycin-treated rats I: magnetic resonance imaging. Epilepsia. 2016;57(1):59-69. doi:10.1111/ epi. 13246

42. Rempe RG, Hartz AMS, Soldner ELB, et al. Matrix metalloproteinase-mediated blood-brain barrier dysfunction in epilepsy. $J$ Neurosci. 2018;38(18):4301-4315. doi:10.1523/JNEUROSCI.275117.2018

43. Simmet T, Tippler B. Cysteinyl-leukotriene production during limbic seizures triggered by kainic acid. Brain Res. 1990;515(1-2):79-86. doi:10.1016/0006-8993(90)90579-Z

44. Theron AJ, Steel HC, Tintinger GR, Gravett CM, Anderson R, Feldman C. Cysteinyl leukotriene receptor-1 antagonists as modulators of innate immune cell function. J Immunol Res. 2014;2014:1-16. doi: $10.1155 / 2014 / 608930$

45. Zhao R, Shi WZ, Zhang YM, Fang SH, Wei EQ. Montelukast, a cysteinyl leukotriene receptor-1 antagonist, attenuates chronic brain injury after focal cerebral ischaemia in mice and rats. $J$ Pharm Pharmacol. 2011;63(4):550-557. doi:10.1111/j.20427158.2010.01238.x

46. Kawai Y, Narita Y, Ogata A, Usui A, Komori K. Therapeutic potential of montelukast, cysteinyl leukotriene receptor 1 antagonist, for aortic aneurysm. Eur J Vasc Endovasc Surg. 2019;58(6):e419. doi:10.1016/j.ejvs.2019.06.1064

47. Health NI. Livertox: clinical and research information on drug-induced liver injury. US Natl Libr Med. 2017.

48. Montuschi P, Sala A, Dahlen S-E, Folco G. Pharmacological modulation of the leukotriene pathway in allergic airway disease. Drug Discov Today. 2007;12(9-10):404-412. doi:10.1016/j.drudis.2007.03.004

49. Saad MA, Abdelsalam RM, Kenawy SA, Attia AS. Montelukast, a cysteinyl leukotriene receptor-1 antagonist protects against hippocampal injury induced by transient global cerebral ischemia and reperfusion in rats. Neurochem Res. 2014;40(1):139-150. doi:10.1007/s11064-014-1478-9

50. Jadidi-Niaragh F, Mirshafiey A. Histamine and histamine receptors in pathogenesis and treatment of multiple sclerosis. Neuropharmacology. 2010;59(3):180-189. doi:10.1016/j.neuropharm.2010.05.005

51. Lin Y-C, Huang M-Y, Lee M-S, et al. Effects of montelukast on M2-related cytokine and chemokine in M2 macrophages. J Microbiol Immunol Infect. 2018;51(1):18-26. doi:10.1016/j.jmii.2016.04.005
52. Wynn TA, Chawla A, Pollard JW. Macrophage biology in development, homeostasis and disease. Nature. 2013;496(7446):445. doi:10.1038/nature12034

53. Liu D, Ge S, Zhou G, et al. Montelukast inhibits matrix metalloproteinases expression in atherosclerotic rabbits. Cardiovasc Drugs Ther. 2009;23(6):431. doi:10.1007/s10557-009-6211-6

54. Biber N, Toklu HZ, Solakoglu S, et al. Cysteinyl-leukotriene receptor antagonist montelukast decreases blood-brain barrier permeability but does not prevent oedema formation in traumatic brain injury. Brain Inj. 2009;23(6):577-584. doi:10.1080/02699050902926317

55. Obermeier B, Daneman R, Ransohoff RM. Development, maintenance and disruption of the blood-brain barrier. Nat Med. 2013;19 (12):1584. doi: $10.1038 / \mathrm{nm} .3407$

56. Wang M-L, Huang X-J, Fang S-H, et al. Leukotriene D4 induces brain edema and enhances CysLT2 receptor-mediated aquaporin 4 expression. Biochem Biophys Res Commun. 2006;350(2):399-404. doi:10.1016/j.bbrc.2006.09.057

57. Takahashi Y, Imai K, Ikeda H, Kubota Y, Yamazaki E, Susa F. Open study of pranlukast add-on therapy in intractable partial epilepsy. Brain Dev. 2013;35(3):236-244. doi:10.1016/j.braindev.2012.04.001

58. Kobylarek D, Iwanowski P, Lewandowska Z, et al. Advances in the potential biomarkers of epilepsy. Front Neurol. 2019;10.

59. Hanisch U-K. Microglia as a source and target of cytokine activities in the brain. In: Microglia in the Regenerating and Degenerating Central Nervous System. Springer; 2002:79-124.

60. Rothhammer V, Quintana FJ. Control of autoimmune CNS inflammation by astrocytes. In: Seminars in Immunopathology. Vol. 37. Springer; 2015:625-638.

61. Vezzani A, Granata T. Brain inflammation in epilepsy: experimental and clinical evidence. Epilepsia. 2005;46(11):1724-1743. doi:10.1111/j.1528-1167.2005.00298.x

62. Awasthi A, Matsunaga Y, Yamada T. Amyloid-beta causes apoptosis of neuronal cells via caspase cascade, which can be prevented by amyloid-beta-derived short peptides. Exp Neurol. 2005;196 (2):282-289. doi:10.1016/j.expneurol.2005.08.001

63. Tang -S-S, Hong H, Chen L, et al. Involvement of cysteinyl leukotriene receptor 1 in A $\beta 1-42$-induced neurotoxicity in vitro and in vivo. Neurobiol Aging. 2014;35(3):590-599. doi:10.1016/j. neurobiolaging.2013.09.036

64. Sima X, Xu J, Li J, Zhong W, You C. Expression of $\beta$-amyloid precursor protein in refractory epilepsy. Mol Med Rep. 2014;9 (4):1242-1248. doi:10.3892/mmr.2014.1977

65. Costa C, Parnetti L, D’Amelio M, et al. Epilepsy, amyloid- $\beta$, and D1 dopamine receptors: a possible pathogenetic link? Neurobiol Aging. 2016;48:161-171. doi:10.1016/j.neurobiolaging.2016.08.025

66. Bales KR, Du Y, Dodel RC, Yan G-M, Hamilton-Byrd E, Paul SM. The NF- $\mathrm{kB} /$ Rel family of proteins mediates $\mathrm{A} \beta$-induced neurotoxicity and glial activation. Mol Brain Res. 1998;57(1):63-72. doi:10.1016/S0169-328X(98)00066-7

67. Weiskirchen R. Commentary: montelukast prevents mice against acetaminophen-induced liver injury. Front Pharmacol. 2019;10:1289. doi:10.3389/fphar.2019.01289

68. Larner AJ. Epileptic seizures in AD patients. Neuromolecular Med. 2010;12(1):71-77. doi:10.1007/s12017-009-8076-Z

69. Elwany NE. Protective effect of montelukast against pentylenetetrazole- induced acute seizures and kindling in mice. ZUMJ. 2015;21(6).

70. Fleck J, Marafiga JR, Jesse AC, Ribeiro LR, Rambo LM, Mello CF. Montelukast potentiates the anticonvulsant effect of phenobarbital in mice: an isobolographic analysis. Pharmacol Res. 2015;94:34-41. doi:10.1016/j.phrs.2015.02.001 


\section{Publish your work in this journal}

The Journal of Experimental Pharmacology is an international, peerreviewed, open access journal publishing original research, reports, reviews and commentaries on all areas of laboratory and experimen-

online and includes a very quick and fair peer-review system. Visit $\mathrm{http}: / /$ www.dovepress.com/testimonials.php to read real quotes from tal pharmacology. The manuscript management system is completely published authors.

Submit your manuscript here: https://www.dovepress.com/journal-of-experimental-pharmacology-journal 